Journal of Social Sciences 5(1): 1-8, 2009

ISSN 1549-3652

(C) 2009 Science Publications

\title{
Computer Usage and Achievement among Adults in Rural Area Malaysia
}

\author{
${ }^{1}$ Abdul Razaq Ahmad, ${ }^{2}$ Norhasni Zainal Abiddin, \\ ${ }^{1}$ Jamaludin Badusah and ${ }^{1}$ Pang Shiau Wai \\ ${ }^{1}$ Faculty of Education, National University of Malaysia \\ ${ }^{2}$ Faculty of Educational Studies, Universiti Putra Malaysia
}

\begin{abstract}
Problem Statement: Previous study showed that most of the adults especially from rural area they are not expert and do not have any knowledge in using computer. Besides that, they cannot afford to buy a computer at home. Due to this problem, Ministry if Rural Development organized the Computer Literacy Program to increase adult's knowledge and skills in using computer. Therefore, the purpose of this article was to study the achievement of adult learners towards Computer Literacy Program which organized by Ministry of Rural Development in Malaysia to increase quality of life among adults in rural communities. Approach: A survey was carried out in Selangor state of Malaysia. A total number of 120 adults from the program were involved; 42 male adults and 78 female adults. Results: The survey showed that the participants have higher achievement in computer usage in the Computer Literacy Programme. Conclusion: It is suggested that a comprehensive assessment should be conducted by Ministry of Rural Development in order to increase quality of life among adults in rural area. The implications of these findings showed that participants have higher achievement in the aspect of knowledge, skills and motivation in computer usage.
\end{abstract}

Key words: Adult education, computer usage, achievement, knowledge, skills, motivation, rural area

\section{INTRODUCTION}

In Malaysia, adult education refers to learning opportunities that are undertaken by adults who seek education outside the formal schooling system ${ }^{[11]}$. In the country, formal schooling is from year 1 (standard 1) to year 11 (when students sit for their Sijil Pelajaran Malaysia examination, which is equivalent to GCE, O level). In the Malaysian context, adult education encompasses both formal education beyond year 11 and the non-formal system. The formal system refers to educational activity at an institution of higher learning that leads to a recognized certificate, diploma or degree. Non-formal education is defined as any organized educational activity outside the established formal education system that is intended to serve identifiable clienteles and specific learning objectives. Adult education in Malaysia focuses more on the non-formal system which includes community education programmes, pre-service vocational skilled training and training at the workplace.

Adult education activities in Malaysia include the government literacy programme personal development, citizenship education, political, ideological and religious studies and employment training. The goals are: (a) to prepare an adult learners for jobs and job enrichment through vocationally oriented education, (b) to promote nation building in a multicultural society through citizenship education, (c) to provide 'alternative education' that allows mature students to continue their education in a non-traditional manner through distance-education programmes and (d) to provide personal enrichment especially to senior citizens through participation in locally organized community programmes ${ }^{[9,10]}$.

Objectives of Ministry of Rural Development are: (a) to increase the income level of rural communities up to $80 \%$ of the income level of urban communities, (b) to establish a knowledgeable and skillful society, (c) to enhance the livelihood of rural residents and (d) to accelerate the implementation of the integrated development concept and programme.

According to $^{[13]}$, adult education is an opportunity of education for the adult which has left the formal education system. These educational opportunities can be formal or non-formal and must utilities methods and

Corresponding Author: Assoc. Prof.Dr. Norhasni Zainal Abiddin, Department of Professional Development and Continuing Education, Faculty of Educational Studies, Universiti Putra Malaysia, 43400 UPM Serdang, Selangor, Malaysia. 
approaches which are appropriate to the experience of participants. Adult education must complete four main objectives. First, adult education must help in motivating adults to accept and make positive changes. Secondly, adult education must encourage the development of knowledge, skills, attitude and creative ideas. Lastly, adult education should be able to help adults to transfer knowledge to their surrounding environment using educational techniques which encourage knowledge application ${ }^{[12]}$.

This study focuses on computer literacy program which provided by Ministry of Rural Development. This program organized in 1998 through the memorandum in between Ministry of Rural Development and IT In-Touch Sdn. Bhd. (represent International Islamic University) on 7 July 1998. The main purpose of Computer Literacy Program is to improve the knowledge and skills in using computer especially for rural communities. The objectives of the study were to (a) evaluate perception of the participants' level of achievement in terms of knowledge, skills and motivation computer usage and (b) investigate the differences of computer usage based on gender, age and salary among participants.

\section{Literature review:}

Learning needs for adults: Robinson ${ }^{[16]}$ defines that adult education as "the entire group of organized activities carried out by a wide variety of institutions for the attainment of educational objectives, it is used to describe the process by which men and women continue learning after formal youth education is completed". Such a definition suggests that the availability of educational opportunities and the delivery of education to adults are important issues in adult education.

Many studies ${ }^{[14]}$ show that competence and performance ability in cognitive achievement can be maintained and education plays a crucial role in this ${ }^{[23]}$. Current research on intelligence shows that older adults are not only able to maintain their knowledge, but also to increase it, meaning the ability to learn is maintained even when changes occur in the process of learning with old age.

This has a concrete significance for the learning of older adults: Despite the decrease in the ability to engage in new knowledge areas and to question prior knowledge, this prior knowledge makes it easier to increase existing knowledge to a higher level of expertise. $\mathrm{In}^{[15]}$ terms, when a person grows older the ability for assimilation increases, while the potential for accommodation decrease. The central importance of prior knowledge of older adults for their continued learning is also recognized in adult education ${ }^{[27]}$ (which takes advantage of these knowledge resources through special didactical concepts, especially in the context of teaching and learning.

Trends and challenges in adult education: Adults normally seek learning to help meet a need. Thus, the basic tenet planning an educational programme for an adult is to take into consideration his or her learning needs. Eight percent of providers surveyed reported that one of the challenges they face is offering programmes that do not meet the learners' learning needs. Some mentioned that learners were not interested in the programme (that probably they were directed by their employer to participate) which may also imply that the programme did not meet their needs. Subsequently learners are not willing to participate actively in the programme's learning activities.

Generally, most of the adult and continuing education programmes provided by the public sector are guided by the national agenda. As a relatively young, developing nation, the government's thrust is on nation building. Hence the trend of available adult and continuing education programme is also of that nature. Very limited programmes that deal with life enrichment are available from the public sector. With better education, more disposable income and a changing lifestyle, it is anticipated that there will be a demand for educational programmes on life enrichment. A study carried out at a suburban community in Malaysia showed that most of the educational programmes attended by people in that community are jobrelated $^{[11]}$. Very few programmes attended were related to the concern of how the people in the community could become better community members and live more meaningful and richer personal lives.

For an instance, e-Sri Lanka PC project of the Information and Communication Technology Agency of Sri Lanka (ICTA) was showcased at Linux Asia 2006 Conference at New Delhi, India. Linux Asia, Asia's premier Open Source Conference for three days included topical sessions and forums along with technology workshops, networking events and special programs. Keynotes and sessions were presented by international experts and panels. Large number of professionals, government officials and undergraduates participated in the event. The objectives of the e-Sri Lanka PC programme is to increase the number of households with PCs in order to improve the ICR literacy of the country.

Definition: Technology mainly refers to the new wave of information and communication technology (ICT), including internet-based communication and transaction systems, mobile devices, computer integrated telephony, groupware, workflow and multimedia. Flexibility and technology are supposed to shape major 
trends in the evolution of quality of work and quality of life in the upcoming "information society" or "knowledge society". Quality of life is measured using specially designed and tested instruments, which measure people's ability to function in the ordinary tasks of living. This may related to the Computer Literacy Program which the adult participants able to increase their knowledge, motivation and develop their skills and their independence in computer usage. Thus, they may apply all of these in their career, work activities and daily life in the future.

Knowledge aspects: Knowledge evolves. So far we may understand it as accumulated external and explicit information belonging to the community being leveraged by tacit intrinsic insights which originate within individuals who then may act alone or cooperatively in order to control or integrate with their environment ${ }^{[20]}$.

The definition of knowledge has transformed over such history, from a general phenomenon, to one that is specialized and actionable as the behaviorists pointed out, in evidence "outside the person, in society and economy, or in the advancement of knowledge itself" ${ }^{[4]}$. To complete this guideline for a contemporary definition of knowledge, to Drucker's external knowledge in action, we must also add a condition validated by ${ }^{[20]}$ and other writers that applying knowledge to action additionally requires an intrinsic or tacit element. We arrive at a definition which may be stated thus: Knowledge evolves. So far we may understand it as accumulated external and explicit information belonging to the community being leveraged by tacit intrinsic insights which originate within individuals who then may act alone or cooperatively in order to control or integrate with their environment $^{[20]}$.

For this study, those aspects which related in computer such as learning to learn Windows, Microsoft Word, Microsoft Excel, Microsoft Power Point and basic skills in using computer which comprised in Computer Literacy Program.

Skills aspects: Skills can be defined as an ability or proficiency that is acquired or developed through training or experience. As the providers of information increasingly utilize web and other IT platforms to deliver their resources, students also require IT skills to access the literature in their field. Furthermore, in order to complete assignments-from essay writing, to presentations, to analysis of data; students will need to develop skills in accessing and using the appropriate software that is available to support these activities. In this context, skills aspects refer to an ability among adults in performing ICT which they learned in
Computer Literacy Program such as skills in using Microsoft Office and surfing internet. In this context, skills aspects focus on the ability among individual to apply and arrange their learning in more creative and innovative way ${ }^{[7,8]}$.

Motivation aspects: Definition of motivation, which is of what people will work to achieve: 'Motivation towards better performance depends on the satisfaction of needs for responsibility, achievement, recognition and growth. Needs are felt and their intensity varies from one person to another and from time to time and so does the extent to which they are motivating ${ }^{[3]}$.

Motivation is important to let adult learners see the progress they are making, acknowledging their contribution to progress, making them aware of the ways they can "have say" in language learning and thereby encouraging them to take a more independent and responsible role in the process. Besides that, motivation able to encourage an adult to use computer more often in their free time, using internet to read newspaper and searching information in internet.

\section{MATERIALS AND METHODS}

This research used a quantitative design carried out as a survey study in Selangor state of Malaysia. A random sample of 120 adult participants from the Computer Literacy Programme was involved in the study. Section 1 of questionnaire determines participants' demographic profiles. Section 2 consists of 30 items related to aspects of knowledge, skills and motivation on a Likert scale.

\section{RESULTS}

The total sample in this programme is 120 participants. For this programme, males dominated $35 \%$ however females dominated at $65 \%$. In term of age range, a majority $(30 \%)$ of participants from the $41-50$ age group and 51-65 age group, followed by 31-40 $(22.5 \%)$ and $16-30$ age group (17.5\%). The monthly income of the participants showed that $67.5 \%$ receiving a monthly salary of USD\$300-USD\$900. About $32.5 \%$ had a monthly salary of USD\$901-USD\$1500.

Table 1 shows the mean score of the achievement of the participants who score highly in knowledge aspect (3.88), followed by motivation aspect (3.70) and skills aspect (3.32).

Table 2 shows the mean scores and standard deviations of the respondents' perceptions regarding the aspect of knowledge, skills and motivation in computer usage towards gender. For all of the aspects, males and females obtained the highest mean score in knowledge aspect (male $=3.89$ and female 3.87). It follows by 
motivation (male $=3.79$ and female 3.65 ) and skills (male $=3.37$ and female 3.29).

Table 1: Mean score of participants and their achievement in computer usage

\begin{tabular}{lll}
\hline Aspects & Mean & Standard deviation \\
\hline Knowledge & 3.88 & 0.52 \\
Motivation & 3.70 & 0.51 \\
Skills & 3.32 & 0.60 \\
\hline
\end{tabular}

Table 3 shows the mean scores and standard deviations of the respondents' perceptions regarding the aspect of knowledge, skills and motivation in computer usage towards age group. Age group of 41-50 obtained the highest mean 3.99 in the aspect of knowledge, age 31-40 obtained the highest mean 3.56 in skills aspect and age 41-50 obtained the highest mean 3.91 in motivation aspect.

Table 4 shows the mean scores and standard deviations of the respondents' perceptions regarding the aspect of knowledge, skills and motivation in computer usage towards salary. There are the differences in between the income of USD\$300-USD\$900 and USD\$901-USD\$1500. The participants obtained the mean score of 3.74 (USD\$300-USD\$900) and 4.18 (USD\$901-USD\$1500) in the knowledge aspect. It follows by motivation aspect and skills aspect.

Table 2: Mean and standard deviation for aspects of knowledge, skills and motivation in computer usage towards gender

\begin{tabular}{|c|c|c|c|c|c|c|}
\hline \multirow{2}{*}{$\begin{array}{l}\text { Gender } \\
(\mathrm{N}=120)\end{array}$} & \multicolumn{2}{|c|}{ Knowledge } & \multicolumn{2}{|c|}{ Skills } & \multicolumn{2}{|c|}{ Motivation } \\
\hline & Mean & SD & Mean & SD & Mean & $\mathrm{SD}$ \\
\hline Male & 3.89 & 0.48 & 3.37 & 0.57 & 3.79 & 0.45 \\
\hline Female & 3.87 & 0.55 & 3.29 & 0.63 & 3.65 & 0.54 \\
\hline
\end{tabular}

Table 3: Mean and standard deviation for aspects of knowledge, skills and motivation in computer usage towards age group

\begin{tabular}{lllllll}
\hline & \multicolumn{2}{l}{ Knowledge } & \multicolumn{2}{c}{ Skills } & \multicolumn{2}{c}{ Motivation } \\
Age group & -------- & ------ \\
$(\mathrm{N}=120)$ & Mean & SD & Mean & SD & Mean & SD \\
\hline $16-30$ & 3.59 & 0.23 & 2.96 & 0.23 & 3.37 & 0.29 \\
$31-40$ & 4.08 & 0.45 & 3.56 & 0.52 & 3.66 & 0.46 \\
$41-50$ & 3.99 & 0.64 & 3.46 & 0.74 & 3.91 & 0.64 \\
$51-65$ & 3.79 & 0.52 & 3.22 & 0.61 & 3.72 & 0.45 \\
\hline
\end{tabular}

Table 4: Mean and standard deviation for aspects of knowledge, skills and motivation in computer usage towards salary

\begin{tabular}{|c|c|c|c|c|c|c|}
\hline \multirow{2}{*}{$\begin{array}{l}\text { Salary } \\
(\text { USD\$) } \\
(\mathrm{N}=120)\end{array}$} & \multicolumn{2}{|c|}{ Knowledge } & \multicolumn{2}{|c|}{ Skills } & \multicolumn{2}{|c|}{ Motivation } \\
\hline & Mean & SD & Mean & SD & Mean & $\mathrm{SD}$ \\
\hline $300-900$ & 3.74 & 0.44 & 3.14 & 0.47 & 3.58 & 0.47 \\
\hline
\end{tabular}

\begin{tabular}{lllllll}
$901-1500$ & 4.18 & 0.57 & 3.70 & 0.69 & 3.93 & 0.54 \\
\hline
\end{tabular}

Table 5 shows the mean scores and standard deviations of the respondents' achievement for the knowledge aspect used in the Computer Literacy Program. The questionnaire used 5 point Likert scale (strongly disagree [1], disagree [2], uncertain [3], agree [4] and strongly agree [5]). The range of the means are as follows:

Overall, respondents have a good achievement $(\mathrm{M}=3.91)$ for knowledge aspect in computer literacy program. Respondents agreed that they understand what they had learned $(\mathrm{M}=4.67)$ and the directions in computer program $(\mathrm{M}=4.47)$. However, the participants were disagree that they are still unable to switch on the computer $(\mathrm{M}=3.40)$ and able to follow the steps in using Microsoft Word $(\mathrm{M}=3.07)$. The data show that much has to done to improve the knowledge in computer usage.

Table 6 shows that the mean and standard deviation of the respondents' achievement for the skills aspect used in computer literacy program. Overall, the respondents seemed have a good achievement $(\mathrm{M}=3.68)$ for skills aspect in computer literacy program. Even though the participants strongly agree that they able to search the information from internet $(\mathrm{M}=4.47)$ and use the computer program $(\mathrm{M}=4.33)$, they disagreed that they are trying to complete the task using computer $(M=3.20)$, able to send an email to friend $(\mathrm{M}=3.20)$ and able to switch on the computer by themselves $(M=3.07)$. The data suggest that the skills in computer usage among adult participants still have to improve.

In terms of the motivation aspect used in the computer literacy program, overall the respondents were have a good achievement $(\mathrm{M}=3.88)$. Table 7 shows that the participants less motivation when learning computer $(\mathrm{M}=3.40)$ and seldom using computer during their free time $(\mathrm{M}=3.40)$. Nevertheless, the participants seemed agreed regarding that they always searching information in internet $(\mathrm{M}=4.60)$ and they also found that learning computer is much enjoyed $(\mathrm{M}=4.87)$.

Table 5: Mean and standard deviation for knowledge aspect used in the computer literacy program

\begin{tabular}{lll}
\hline Item & \multicolumn{1}{c}{$(\mathrm{N}=120)$} & SD \\
\hline 1. & I able to follow the steps to switch on the computer. & 3.73 \\
2. & I found that jot down the steps of using computer is useful for me. & 4.40 \\
3. & I understand the directions in computer program. & 4.47 \\
4. & I able to follow the steps in using Microsoft Word. & 3.07 \\
5. & I am trying to understand what I learned. & 1.70 \\
6. & I am still unable to switch on the computer. & 1.83 \\
7. & I able to differentiate in between monitor and keyboard. & 3.00 \\
8. & I know the steps in using printer. & 1.27 \\
9. & I understand what I had learned. & 1.65 \\
\end{tabular}




\begin{tabular}{|c|c|c|c|}
\hline 10. & $\begin{array}{c}\text { know the function of CD/DVD Rom. } \\
\text { Total }\end{array}$ & $\begin{array}{l}4.40 \\
3.91 \\
\end{array}$ & 1.80 \\
\hline \multicolumn{4}{|c|}{ Table 6: Mean and standard deviation for skills aspect used in the computer literacy program } \\
\hline Item & $(\mathrm{N}=120)$ & Mean & SD \\
\hline 1. & I able to switch on the computer by myself. & 3.07 & 1.27 \\
\hline 2. & I am expert in using Microsoft Word. & 3.93 & 1.64 \\
\hline 3. & I am expert in using Microsoft Power Point. & 4.13 & 1.72 \\
\hline 4. & I unable to use computer program. & 4.33 & 1.80 \\
\hline 5. & I able to search information from internet. & 4.47 & 1.83 \\
\hline 6. & I unable to search the information from internet. & 3.53 & 1.44 \\
\hline 7. & I am trying to complete the task using computer. & 3.20 & 1.31 \\
\hline 8. & I am expert in using Microsoft Excel. & 3.40 & 1.40 \\
\hline 9. & I able to read newspaper from internet. & 3.53 & 1.44 \\
\hline \multirow[t]{2}{*}{10.} & I able to send an email to my friend. & 3.20 & 1.31 \\
\hline & Total & 3.68 & \\
\hline
\end{tabular}

Table 7: Mean and standard deviation for motivation aspect used in the computer literacy program

\begin{tabular}{llll}
\multicolumn{1}{c}{$(\mathrm{N}=120)$} & Mean & \\
\hline Item & \multicolumn{1}{c}{ SD } \\
\hline 1. & I am trying my best to understand how to use computer. & 3.67 & 1.51 \\
2. & I am using Microsoft Word for typing more often. & 3.73 & 1.53 \\
3. & I am trying to use other programmes in computer. & 3.67 & 1.51 \\
4. & I feel more motivation when learning computer. & 3.40 & 1.40 \\
5. & I am always searching information in internet. & 4.60 & 1.88 \\
6. & I found that learning computer is much enjoyed. & 4.87 & 1.90 \\
7. & I wish to continue learning computer. & 4.00 & 1.63 \\
8. & I pay attention when learning computer. & 3.47 & 1.63 \\
9. & I like to read newspaper from internet. & 3.40 & 1.45 \\
10. & I am using computer during free time. & 3.88 & \\
& Total & & 1.40 \\
\hline
\end{tabular}

\section{DISCUSSION}

Application of Information and Communication Technologies (ICT) in adult learning has expanded greatly. ICT encompasses capturing, storage, processing, communications and display technologies. Three aspects that the article focuses on are competency in knowledge, skills and motivation in computer usage. Having a wider knowledge in using computer will help the adult participants and everyone to use computer more useful and more often. According to ${ }^{[5]}$, in which only a minority of participants believed that they were making good progress. Perhaps one explanation for this finding attribute that these adults do not perceive being well in their computers skills if compare with knowledge and motivation in computer usage. In their minds, doing well is primarily about developing all the computer usage especially in knowledge, skills and motivation aspects and overall competence to a level which they have set themselves. Such a perception of success would be similar to that demonstrated by the population $\mathrm{in}^{[5]}$ study, where developing skills, knowledge and motivation in computer usage and achieving the expectations of the achievement was much more difficult.

Non-formal adult education refers to learning opportunities that take place outside the formal educational system. In this study, the Computer
Literacy Program which provided by Ministry of Rural Development is more flexible in time and more responsive to localized needs (Merriam \& Brockett). This program is popular in reference to communitybased programmes where the goal is development in participant's knowledge, skills and motivation in computer usage and in some case, social change. Coomb's third category, informal adult education, is unplanned learning, that is, the byproduct of engaging in other activities-"the spontaneous, unstructured learning that goes on daily in the home and neighborhood" ${ }^{[2]}$. It is also related with the participant's daily life, work activities and their career with their achievement in computer While technically not a delivery system since this kind of learning is unsystematic, Coombs and others make the point that it is probably the most prevalent form of adult learning and thus nations can systematically enrich the environment in which it takes place (for example, the facilities in the centre are up-to-date, strategic location for the participants to attend the computer class, the teaching process is well-planned and the instructors able to deliver the course in more creative and enjoyful way).

Ideally, every nation has as the purpose of its education programme to improve the living conditions of its citizens. Titmus ${ }^{[24]}$ has identified four such goals 
which parallel with the objectives of computer literacy programme:

- Second-chance education, which offers adults who missed it the kind of education obtainable in the initial education system. This may range from basic literacy to mature entrance to university

- Role education, which is education for social function (outside employment) and includes social role education (e.g., as a citizen, member of an association) and personal role education (e.g., as a parent, spouse, retired person)

- Vocational education, that is, education in the skills and knowledge required in employment

- Personal enrichment education or education intended to develop the individual without regard to his or her social or economic function which includes, in effect, anything not covered by the other headings

With a wider of knowledge and understanding about computer will motivate someone to feel more interest in learning computer ${ }^{[18,28]}$. Besides that, positive motivation can lead the adults to learn more and have the higher achievement in computer learning. This is similar to what was found in the studies by ${ }^{[13,25]}$, which computer or ICT is the wave of the future. This idea also agreed by Koohang and Byrd ${ }^{[18]}$ that higher motivation in learning computer able to increase the knowledge and develop the skills among participants indirectly. Furthermore, Jonassen ${ }^{[6]}$ indicates that someone who always searching the information from internet are those who have higher motivation in using computer.

Saifuddeen ${ }^{[19]}$ comment, mastering Information Communication and Technology (ICT) knowledge already became insistence in the future. Individual who defined knowledgeable in computer if that person have positive attitude and responsible in using computer; effort to evaluate, elect and using various computer application; can using hardware and software which appropriate with computer application; and expert in computer operating through the programming ${ }^{[21]}$. Technology development moving quickly make happen knowledge and skills in ICT increase important to fulfill the work market needs and industry which need the workers who expert in using ICT. Effectiveness using ICT in some matter always related to skills of ICT in that person.

Attitude was important element in education field. Instructors who have positive attitude can make teaching and learning process more effective. This is because they can actuate learners learning in the class.
As Zulkifli ${ }^{[28]}$, positive attitude was essential to actuate someone to learn something. If instructors have negative attitude towards using ICT in teaching and learning, it will become barrier to teaching and learning process.

Nonetheless, it is important to define the preparation level in teaching and learning from aspect of knowledge, skills and motivation. On the other hand, strong support from the government essential to expedite the development of knowledge, skills and motivation in learning computer among adult participants.

\section{CONCLUSION}

Future adult learners need differing knowledge and skills to become "knowledge workers" ${ }^{[22]}$. In striving to achieve Vision 2020, Malaysia has placed importance on human resource development as a vehicle towards realizing the goals of Vision. Adult education will play a major role in producing a knowledge workforce with competency in basic skills in literacy, numeracy and operacy in thinking ${ }^{[26]}$.

Many methods and techniques in adult learning have developed over the past years and more recently computer-mediated instruction has become popular. Online education or learning networks have opened up vast opportunities for remote learners to acquire knowledge and skills. ICT can enhance existing methods and techniques but ICT should be used as a tool for re-engineering the learning process thus making learning more effective ${ }^{[1]}$.

The correct choice of methods and techniques in delivering adult education determines its effectiveness and in the long run can create knowledge workers. The technique design should help build the basic skills and help foster the necessary knowledge, skills and motivation among adult learners. The proper technique applied has the potential to nurture skills and critical thinking, knowledge construction and collaborative learning. These skills would empower adults to become self-directed learners. Whatever the choice of methods, self-directed learning should be central theme in future adult learning.

Adult and continuing education has been practiced for six centuries in Malaysia. However, the subject is not well established as a field of study. Very limited systematic inquiry has been done in the area. Neither is there any specific professional association or independent body that links all the stakeholders in the field. To meet the needs of both the individual and the 
nation, there is a dire need for the field to be well established.

\section{REFERENCES}

1. Abu Daud Silong, Daing Zaidah and Azizan Asmuni, 1998. Self-directed learning and online technologies: Reengineering the learning process. Proceeding of the ACADEMIA'98 National Position Conference on Education and Technology, Mar. 6-7, Sunway Pyramid Convention and Exhibition Centre, Subang Jaya, Selangor, pp: 1-10. http://vlib.unitarklj1.edu.my/staffpublications/daing/academiaasia.pdf.

2. Coombs, P.H., 1985. The World Crisis in Education: The View from the Eighties. 1st Edn., Oxford University Press, New York, ISBN: 019503502X, pp: 353.

3. Davidmann, M., 1970. Work, Remuneration and Motivation of Directors. 1st Edn., Social Organisation Ltd., UK.,ISBN-10: 0851920039, pp: 39.

4. Drucker, P.F., 1993. The Daily Drucker: 366 Days of Insight and Motivation for Getting the Right Things Done. HarperCollins Business, New York, ISBN-10: 0060742445, pp: 254.

5. Jernigan, C., 2004. What do students expect to learn? The role of learner expectances, beliefs and attributions for success and failure in student motivation. Curr. Iss. Educ., 7. http://cie.asu.edu/volume7/number4/index.html.

6. Jonassen, D.H., 2000. Computer as mind tools for schools: Engaging critical thinking. 2nd Edn., Prentice Hall, Merrill, New Jersey, USA., ISBN10: 0130807095 , pp: 297.

7. Light, G. and R. Cox, 2001. Learning and teaching in higher education. The Reflective Professional, 2nd Revised Edn., Sage Publications Ltd., London, ISBN-10: 1848600089 , pp: 126.

8. Likone, T., 1993. The return of character education. Educ. Leadership, 51: 6-11. http://www.hi-ho.ne.jp/taku77/refer/lickona.htm.

9. Malaysia Government. 2001. The eighth Malaysia plan 2001-2005. The Economic Planning Unit Prime Minister's Department, Putrajaya. http://www.epu.jpm.my/new\%20folder/developme nt\%20plan/RM8/c13_cont.pdf

10. Malaysia Government, 2006. The ninth Malaysia plan 2006-2010. The Economic Planning Unit Prime Minister's Department, Putrajaya. http://www.epu.jpm.my/rm9/english/Chapter5.pdf

11. Mazanah, M., 2001. Adult and Continuing Education in Malaysia. 1st Edn., Universiti Putra
Malaysia, Kuala Lumpur, ISBN: 9789832373032 , pp: 142.

12. McLagan, P.A., 1978. Helping others Learn: Designing Programs for Adults. 1st Edn., Addison Wesley, Sydney, ISBN-10: 0201046172, pp: 101.

13. Naisbitt, J., 1999. High Tech, High Touch: Technology and our Search for Meaning. 1st Edn., Nicholas Brealey Publishers, London, ISBN-10: 0767903838, pp: 288.

14. Oswald, W.D., 2000. 'Psyhological hypothesis of age(ing), in manual for the formulation of the elderly, theories and concepts for the present and future, Opladen: Leske and Budrich, pp: 107-117

15. Piaget, J., 1971. Genetic Epistemology. W.W. Norton and Company, New York, ISBN-10: 0393005968, p: 1-1.

16. Robinson, D., 1961. Training for Impact. 1st Edn., Jossey-Bass, San Franciso, ISBN-10: 1555421539, pp: 153.

17. Rogers, C. R., 1993. Freedom to Learn for the 80's, $2^{\text {nd }}$ Revised Edition, Merrill, Columbia, OH, ISBN10: 0675200121, pp: 239.

18. Roslina, I., 1999. Knowledge, understanding and attitude in computer literacy among graduated teachers from Islamic Teachers College (MPI). Master Thesis. University Putra Malaysia, Kuala Lumpur. http://www.geocities. com/kamaruzzaman98/BAB5.htm.

19. Saifuddeen, S. M. 2000. Understanding Islamic through Information Technology and Communication, Islamic Institute, Kuala Lumpur, Malaysia, pp: 1-6.

20. Schon, D.A., 1987. Educating the Reflective Practitioner: Toward a New Design for Teaching and Learning the Professions. 1st Edn., JosseyBass, San Francisco, ISBN-10: 1555422209, pp: 89.

21. Simonson, M.R., M. Maurer, M. Montag-Torardi and M. Whitaker, 1987. Development of a standardized test of computer literacy and a complex anxiety index. J. Educ. Comput. Res., 3: 231-247.

22. Tapscott, D., 1996. The Digital Economy: Promise and Peril in the Age of Networked Intelligence. 1st Edn., McGraw-Hill, New York, ISBN-10: 0070633428, pp: 342.

23. Tippelt, R., 1992. Constructive ageing-a challenge for adult education and for the individual, Frankfurt: DVV, pp: 66-74

24. Titmus, C.J., 1989. Lifelong Education for Adults: An International Handbook, 1st Edn., Pergamon Press, New York, ISBN-10: 0080308511, pp: 629. 
25. Toffler, A., 1974. Learning for Tomorrow- the Role of the Future in Education. Random House, New York, ISBN-10: 0394483138, pp: 145.

26. Ungku, A.A., 1997. Human Resource Development: The Education and Training Aspect. In: Malaysia's Vision 2020: Understanding the Concept, Implications and Challenge, Ahmad, S. (Ed.). Pelanduk Publications, Selangor, Malaysia, ISBN: 9679784711, pp: 97.

27. Wenke, R. J., 1996. Vocational Training for Older Workers: A Manual for Educational Institutions. Bertelsmann, Bielefeld, ISBN: 3763900543, pp: 102.
28. Zulkifli Abdul Manaf and Raja Maznah Raja Hussain. 1994. Attitudes, knowledge and previous computer experience of teacher trainees in the diploma of education programme at the University of Malaya. J. Pendidikan, 16: 1-9. 